\title{
The Dynamic of Current Account in Emerging East-Asian: Does Exchange Rate Matter?
}

\author{
S. K. Sek and C.L. Chuah
}

\begin{abstract}
The aim of this project is to study the dynamics of a country's current account with the change of currency exchange rate. This phenomenon becomes more significant when the 1997 financial crisis hits Southeast Asian countries like Malaysia, Indonesia, Singapore, Korea, Thailand and the Philippines. Collected data will be divided into two sub-periods, pre- and post-crisis. By method, the changes can be presented clearly and concretely. In addition, the method of Structural Vector Auto Regressive, SVAR model will use as methodology in this project. Three variables are selected to study for the changes, current account/GDP, CPI and Exchange rate. After the analyzed, we found that actually current account do not change much expected after the crisis. Countries have changed their country financial policy to reduce the impact of fluctuation of currency exchange rate that has long worried. Inflation targeted policy has been become the preferred and priority.
\end{abstract}

Index Terms-exchange rate, current account dynamics, structural shocks, trade balance

\section{INTRODUCTION}

Movements or fluctuations of a current account in a country's balance of payments have been a hot topic of debates among researchers. Many theories were proposed to explain the phenomena and causes of current account imbalances. Around the world, countries at South-East region have attracted the interest of economists and researchers due to the abnormal trend or reverse trend from the common and classical economic theory in their country's current account especially after the financial crisis of 1997-98. It is reported that the current account balances of China, Hong Kong, Indonesia, Korea, Malaysia, Philippines, Singapore, Taiwan and Thailand have moved from the aggregate deficit of $\$ 27$ billion in 1995 to a surplus of $\$ 186$ billion in 2004, which implies an increase of $6.5 \%$ of GDP [1] The movement from large deficits to surplus has hit and challenged the classical theory of the current account. In norm, developing countries are expected to suffer for current account deficits at the early stage in order to get smooth and easy economic growth inside their country because developing countries are tended to borrow and import.

Manuscript received June 27, 2011; revised July 31, 2011.

Dr. S. K. Sek is a Senior Lecturer of School of Mathematical Sciences, Universiti Sains Malayisa, 11800 Minden, Penang, Malaysia. (e-mail: sksek@ usm.my).

C. L. Chuah is a undergraduate student from the School of Mathematical Sciences, Universiti Sains Malaysia, 11800 Minden, Penang, Malaysia. (e-mail: chuah-c@hotmail.com).
After the exposure of the miseries of the current account in the South East Asian countries, a number of studies seeks to get a proper explanation towards the changes in the current account in these emerging markets and investigates the dynamics of current account globally. A broad consensus looks from the aspect of financial development and international financial integration (among them are [2], [3] and [4]). Others look at the conventional macroeconomics factors, the environmental factors [5] and [1]; global saving glut hypothesis [6] and the role of exchange rate [7].

Taking the initiative from previous studies, this paper seeks to investigate if exchange rate movement is one of the main factors that contribute to current account changes. This paper takes different approaches to focus the analysis on the individual East-Asian developing countries that have experienced the bitter of financial crisis of 1997-98. Since most of these countries have experienced a drastic change in their exchange rate regimes and changes in the current account from a deficit to surplus after the financial crisis, it is informative to conduct analysis on the inter-relationship between current account and exchange rate movements in these countries. This paper has two main objectives. First, it seeks to investigate if the exchange rate movements can affect the current account dynamics. This investigation is conducted to compare the data of pre- and post-crisis periods. Therefore, the second objective is to investigate the impact of exchange rate movements on current account changes in East Asian countries' changes between the two sub-periods. A new methodology, called Structural VAR will be used to analyze the data and implementing the result of this project. The results reveal that the impact of exchange rate shock on current account balance had declined apparently between two sub-periods in all economies, especially in the case of Korea Philippines and Thailand. i.e.: these three economies, exchange rate shock has impact on current account balances in the pre-crisis, but after the crisis, the impacts on current account balances are from current account and/or CPI shocks. Therefore, the conclusion is exchange rate shock had no significant impact on current account balances after the crisis in ASEAN economies except Malaysia. The main determinants of current account balances after the crisis are mainly from current account real shock and CPI nominal shocks.

The remaining sections are organized as follows: section two is the literature review; section three explains the methodology; section four is about the data; section five summarizes the results and section six concludes. 


\section{LITERATURE REVIEW}

A bulk of studies seeks to reveal the factors that contribute to the current account dynamics globally. There are different macroeconomic factors that can impact the current account changes. One of the factors is exchange rate movement/regimes. In theory, the exchange rate will have an impact on the current account. If there is depreciation in the exchange rate, then that particular country will experience a fall in the foreign price of its exports. It will appear to be more competitive and therefore, there will be a rise in the quantity of exports. Assuming demand for exports is relatively elastic than depreciation in the exchange rate, this will lead to an increase in the value of exports and therefore, improve the current account deficit. Similarly, a depreciation of the exchange rate, will also lead to an increase in the cost of buying imports. Hence, causes a fall in demand for imports and help to reduce the current account deficit. Therefore, in theory, depreciation in the exchange rate should improve the current account and an appreciation should worsen the current account. However, previous studies report quite different remarks. Some studies reveal significant impact of exchange rate movement/ regimes on current account dynamics, either divert or individually (through its impacts on output growth, relative price effect, credit cycle etc). On the other hand, other studies show the contradict results, i.e. exchange rate has no significant impact on current account dynamics.

The studies that report significant relationship between current account and exchange rate includes: [8], [9], [10] $\&$ [11] etc. [8] focus their study in Euro countries. They seek to find the linkage between the movements of the current account to those of real exchange rates from year 1975 to 2005 . Their results demonstrate that there is a positive relationship between the movements of the real exchange rates and the current account in majority of the EMU-member states. On the other hand, [9] analyse the relationship between the nominal exchange rate volatility and several macroeconomic variables (real per output growth, excess credit, foreign direct investment (FDI) and the current account balance) in the Central and Eastern European EU Member States. Using panel estimations for the period between 1995 and 2008, their results show that lower exchange rate volatility is linked to higher growth, higher stocks of FDI, higher current account deficits, and higher excess credit.

[12] examines the relationship between the exchange rate regime and current account adjustment. Their panel data consist of to 11 catching-up countries from Central, Eastern and South-Eastern Europe between year 1994 to 2007. A continuous $\mathrm{z}$-score is used as a measure of exchange rate volatility. Based on basic auto regression estimation, the results indicate that a more flexible exchange rate regime significantly enhances the rate of current account adjustment. [11] use standard computable general equilibrium (CGE) to analyse the economics of the country Sudan. They prove that devaluation of Sudan's currency has improved their country international competitiveness and balance of payments. The impact of the exchange rate on the country balance of the current account is dependent on the changes in expenditure associated with the exchange rate. On the other hand, [13] analyse the economics of China since year 1980 to 2009 by using various methods like Basic Bivariate, cross-section approach and time series approach. Their results show diffuse relationship between real per capita income and the real value of a currency in purchasing power parity. There are some evidences that Chinese trade flows respond to the change in real exchange rates. The real exchange rate effect on overall trade flows is relatively small and sometimes it goes through the opposite direction of anticipated results.

Studies that report either weak or no significant impact of exchange rate on current account include: [14], [15], [16], \& [10] etc. [14] examines Nepal's economics using hypothesis test and Ordinary Least Square (OLS) method regression. He proves that the exchange rate devaluation may not a necessary way to improve the trade balance. The fiscal tools, such as increase the efficiency of tax administration and establish the import substitution type of industries can help to reduce imports. [16] analyse the role of asset prices in comparison to other factors and in particular exchange rates as a driver of the US trade balance by using a Bayesian structural VAR Model. They find that equity market shocks and housing price shocks are the major determinants of the U.S. current account. However, the shocks to real exchange rates have less impact on U.S. current account. Their findings suggest that exchange rate movements may not necessarily a key element in correcting the large current account imbalances. However, the relative global asset price changes could be a potential source of current account adjustment.

Apart from these findings, [15] investigate from year 1970 to year 2005 about the growth of U.S. current account deficit and the potentially sharp exchange rate movements. They find that Asia's greater openness to trade implies that the requisite exchange rate adjustment in Asia is not much greater than Europe's. On the other hand, [10] analyse the issue of current account adjustment across different exchange rate regimes in a sample of industrialized countries like U.S., Europe countries, Australia, and New Zealand over the period of $1970-2007$. They also estimate a treatment effects model for each exchange rate regime group to identify the effects of a current account correction on real GDP growth. They state that there are not relevant differences in the dynamics of the main macroeconomic variables around the adjustment episodes across diverse exchange rate systems. They find that the highest cost of an adjustment is under a flexible exchange rate regime.

\section{Methodology}

We apply a structural vector autoregressive (SVAR) model to analyze the dynamic of current account with various economic indicators (CA/GDP, Nominal Exchange rate, CPI). SVAR enables identification on the structure (temporary or permanent) of shocks and provides analysis on the transmission of shocks through impulse response function and forecast error variance decomposition. This research consists of three endogenous 
variables: current account/GDP (y), Consumer Price Index (CPI) and real exchange rate (ex). The CPI and real exchange rate are mentioned in logarithm form in order to get the value in percentage:

$$
X=[\Delta y, \quad \Delta C P I, \quad \Delta E X]
$$

where $\Delta$ indicates the first/second operator. The VAR model can be represented in structural form as:

$$
\begin{aligned}
& A_{0} X_{t}=A_{1} X_{t-1}+\ldots .+A_{q} X_{t-q}+B s_{t} \\
& A_{o} X_{t}=\sum_{i=1}^{q} A_{k} X_{t-1}+B \varepsilon_{t} \quad i=1, \ldots, q
\end{aligned}
$$

where $X$ is a $(K \times 1) ; K=3$ vector of endogenous variables; $A_{o}$ and $B$ are the $(K \times K)$ matrices which show the instantaneous relationship of variables in $X$ and $\varepsilon$ respectively ; $A_{i}$ 's are $(K$ $\times \mathrm{K})$ coefficient matrices given $(\mathrm{i}=1, \ldots, \mathrm{q})$ and $\varepsilon_{\mathrm{t}}$ is the $(\mathrm{K} \times 1)$ vector of structural shocks. $\varepsilon_{\mathrm{t}}$ consists of three shocks, i.e. CA/GDP ( $\left.\mathcal{E}^{y}\right)$ shocks, CPI shocks ( $\varepsilon^{c p i}$ ) and the exchange rate shocks $\left(\varepsilon^{e x}\right)$.

$$
\mathcal{E}_{t}=\left[\mathcal{E}_{t}^{y}, \mathcal{E}_{t}^{c p i}, \mathcal{E}_{t}^{e x}\right]
$$

In this model, $\varepsilon_{\mathrm{r}}$ is independently multivariate normal (IMN) distributed with mean value of zero. It is mutually uncorrelated and stable or positive definite. i.e.: $\mathcal{E}_{t} \sim \mathrm{IMN}$ $(0, \Sigma)$. By pre-multiplying both sides of variables with $\mathrm{A}_{o}^{-1}$, the structural form of equation (1) can be transformed into reduced form:

$$
X_{t}=\bar{A}_{1} X_{t-1}+\ldots+\bar{A}_{q} X_{t-q}+e_{t}
$$

Where $\bar{A}_{k}=A_{o}^{-1} A_{k}, j=1, \ldots, q ; e_{t}=A_{o}^{-1} B \varepsilon_{t}$, denote the link between the reduced form of disturbance and the structural shock.

The long-run identifications model that suggested by [17], sets Ao as an identity matrix, i.e. Ao=Ik and imposes no restriction on $\mathrm{B}$ matrix such that $\mathrm{et}=\mathrm{B} \varepsilon \mathrm{t}$. The long run restrictions imposed on the cumulative impulse response function. In order to allow $[\mathrm{Ao}-\mathrm{A}(\mathrm{L})]$ matrix to be invertible, all variables in the VAR should be in stationary conditions.

Under the [17] identification, the long-run impact matrix is in lower triangular choleski decomposition. This means that the first $\varepsilon_{t}$ shock may have an instantaneous effect on all variables, the second shock has no impact on the first variable but it can have influences on the variables below it. This rule applies to all subsequent variables. So, under the lower triangular choleski decomposition, the ordering of the variables in the system equation matters in generating different effects of shocks. The long-run impact matrix can be written in the following form:

$$
\left(\begin{array}{l}
e_{t}^{y} \\
e_{t}^{q p^{2 i}} \\
e_{t}^{e x}
\end{array}\right)=\left(\begin{array}{ccc}
C(1)_{11} & 0 & 0 \\
C(1)_{21} & C(1)_{22} & 0 \\
C(1)_{31} & C(1)_{32} & C(1)_{33}
\end{array}\right)\left(\begin{array}{c}
\varepsilon_{t}^{y} \\
\varepsilon_{t}^{g i} \\
\varepsilon_{t}^{e x}
\end{array}\right)
$$

where $\mathrm{C}(1)=\sum_{i=0}^{\infty} C_{i}$

\section{A. Impulse Response Function (IRF)}

As mentioned in [18] equation (1) can be transformed as:

$$
\left(I_{k}-A(L)\right) X_{t}=B \varepsilon_{t}
$$

where, $A(L)=\sum_{i=1}^{q} A_{i} L_{i}$ and $A_{o}=I_{k}$ in order to get it invertible.

By inverting [Ik-A(L)], we get the Wold moving average representation of SVAR process:

$$
X_{t}=C(L) \varepsilon_{t}=C_{o} \varepsilon_{t}+C_{1} \varepsilon_{t-1}+\ldots+C_{s} B_{t-s}
$$

where $C(L)=\left(I_{k}-A(L)\right)^{-1}$ and $C_{o}=B$.

$\mathrm{A}_{0}$ is identified to be an identity matrix and $e_{t}=A_{0}^{-1} B \varepsilon_{t}=B \varepsilon$, we obtain $\varepsilon_{t}=B^{-1} e_{t}$ Substitute this relationship into equation (3) to obtained:

$$
X_{t}=C(L) \varepsilon_{t}=C(L) B^{-1} \varepsilon_{t}
$$

Equation (4) can be written in a Wold representation of the reduced form VAR process:

$$
X_{t}=D_{0} e_{t-1}+\ldots+D_{s} e_{t-s}
$$

where $D_{i}=C_{i} B^{-1}, D_{0}=I_{k}$ and $i=0,1 \ldots$.

The reduced form of the forecast error impulse response function coefficients can be interpreted as:

$$
D_{s}=\frac{\partial X_{t+s}}{\partial e_{t}}=\sum_{j=1}^{s} D_{s-j} A_{j}
$$

The elements $\{i, j\}$ of matrix Ds indicates the expected response of $\mathrm{Xi}, \mathrm{t}+\mathrm{s}$ due to an impulse or a unit change in $\mathrm{Xij}$. The accumulated Impulse Response Function can be obtained from the matrix of the long run effect:

$$
D=\sum_{s=0}^{\infty} D_{s}=\left(I_{k}-A_{1}-\ldots . .-A_{q}\right)^{-1}
$$

\section{B. Forecast Error Variance Decomposition (FEVD)}

Another tool used to interpret the VAR model is the forecast error variance decomposition (FEVD). This tool is constructed as the h-step forecast error from the structural innovations:

$$
X_{T+h}-X_{T+h \mid T}=C_{0} \varepsilon_{T+h}=C_{1} \varepsilon_{T+h-1}+\ldots+C_{h-1} \varepsilon_{T+1}
$$

Denoting the ij-th element of $\mathrm{Cn}$ as $\mathrm{Cij}, \mathrm{n}$, the k-th element of the forecast error vector can be written as:

$$
X_{k, T+h}-X_{k, T+h \mid T}=\sum_{n=0}^{h-1} C_{k 1, n} \varepsilon_{1, T+h-n}+\ldots+C_{k K, n} \varepsilon_{K, T+h-n}
$$

The forecast error variance is constructed as the following with the precondition that the structural disturbances are not contemporaneously and serially correlated:

$$
\sigma_{k}^{2}(h)=\sum_{n=0}^{h-1}\left(C_{k 1, n}^{2}+\ldots+C_{k K, n}^{2}\right)=\sum_{j=1}^{K}\left(C_{k j, 0}^{2}+\ldots+C_{k j, h-1}^{2}\right)
$$

The term in bracket on the right hand side of equation (10) indicates the contribution of variable $\mathrm{j}$ to the forecast error variance of variable $\mathrm{k}$ for h-step horizon.

\section{DATA}

We examine the dynamic of the current account in Singapore, Malaysia, Indonesia, Philippines, Thailand, and Korea. The data that we used in the analysis are consumer price index (CPI), gross domestic product (GDP) 
(in million USD), current account (CA) (in million USD) and nominal exchange rate per USD (EX). All data are collected from International Financial Statistics, IMF and Datastream. The data are in quarterly, ranging from 1980Q1 to 2010Q4. The data are divided into pre-crisis period (1980Q1 to 1997Q2) and post- crisis period (1999Q1 to 2010Q4). We three variables that entered the system equation of structural VAR are log CPI, log exchange rate and the ratio of the current account to GDP. Due to the data availability problem, we only include the analysis of post-crisis period for Thailand.

Under the Blanchard-Quah identification, all variables in the system equation should be in stationary form. The non-stationary variables are transformed into stationary one through the first differenced operator before conducting the analysis. The Augmented Dickey-Fuller (ADF) unit root test is used to check the stationary condition of the variables.

Table 1 is the descriptive statistic on each variable. Comparing the data between the two sub-periods, we observe that most of the countries have improved their current account from a large deficit to surplus. i.e.: the mean for CA/GDP has change from negative value to positive value for Indonesia, Korea and Malaysia except Singapore shows a lower surplus after the crisis compare to before crisis.

Meanwhile, for the countries' CPI, we observe an increasing trend of $\log$ CPI compare with that of the pre-crisis. The range of increment is from 0.645 to 1.028 . It shows that most of the East Asian countries perform an expansionary monetary economy after the ' 97 crisis. The exchange rate also gives a common trend where most of the countries have a larger mean after the crisis. It may due to the switch of the exchange rate regime where most of these countries have allowed their home currency to fluctuate freely after the crisis. The exchange rate has larger flexibility after the crisis in Indonesia, Korea, Philippines and Thailand. On the other hand, Malaysia and Singapore have shown a reverse result due to the unique policy taken.

TABLE 1: Descriptive Statistic

\begin{tabular}{|c|c|c|c|c|c|c|c|c|c|c|c|c|}
\hline Country & \multicolumn{2}{|c|}{ Indonesia } & \multicolumn{2}{|c|}{ Korea } & \multicolumn{2}{|c|}{ Malaysia } & \multicolumn{2}{|c|}{ Philippine } & \multicolumn{2}{|c|}{ Singapore } & \multicolumn{2}{|c|}{ Thailand } \\
\hline Period & Pre & Post & Pre & Post & Pre & Post & Pre & Post & Pre & Post & Pre & Post \\
\hline \multicolumn{13}{|c|}{ Current Account/GDP } \\
\hline Mean & -0.0258 & 0.0238 & -0.0124 & 0.0270 & -0.0610 & 0.0133 & -0.0134 & -0.0278 & 0.0654 & 0.0184 & 0.0596 & 0.0813 \\
\hline $\begin{array}{l}\text { Standard } \\
\text { deviation }\end{array}$ & 0.0127 & 0.0230 & 0.0185 & 0.0289 & 0.0455 & 0.0412 & 0.0126 & 0.0141 & 0.0737 & 0.0540 & 0.0929 & 0.0937 \\
\hline \multicolumn{13}{|l|}{ Log CPI } \\
\hline Mean & 0.0279 & 0.0444 & 0.0133 & 0.0198 & 0.0173 & 0.0199 & 0.0105 & 0.0208 & 0.0428 & 0.0450 & 0.0165 & 0.0196 \\
\hline $\begin{array}{l}\text { Standard } \\
\text { deviation }\end{array}$ & 0.0401 & 0.0389 & 0.0429 & 0.0477 & 0.0129 & 0.0358 & 0.0550 & 0.0827 & 0.0100 & 0.0495 & 0.0146 & 0.0416 \\
\hline \multicolumn{13}{|c|}{ Log Exchange Rate } \\
\hline Mean & 0.0726 & 0.0907 & 0.0663 & 0.0703 & 0.0919 & 0.0129 & 0.0292 & 0.0385 & 0.0617 & 0.0483 & 0.0320 & 0.0364 \\
\hline $\begin{array}{l}\text { Standard } \\
\text { deviation }\end{array}$ & 0.0457 & 0.0271 & 0.0974 & 0.0131 & 0.0643 & 0.0768 & 0.0438 & 0.0149 & 0.0159 & 0.0852 & 0.0718 & 0.0114 \\
\hline
\end{tabular}

\section{RESUlts}

In this paper, a suitable endogenous lag had been chosen together with a constant term with or without trend and seasonal dummies depending on the pattern of the time series. Since the availability of the data is not too long (Thailand start from 1992Q1), so the endogenous lag is normally depend on the data availability and Akaike info criterion and Schwarz criterion. Table 2 summarizes the model speci- fications:

TABLE 2: MODEL SPECIFICATION

\begin{tabular}{l|c|c|c|c}
\hline \multicolumn{1}{c}{ Country } & Constant & Trend & $\begin{array}{c}\text { Seasonal } \\
\text { dummy }\end{array}$ & No. of lag \\
\hline Indonesia pre & $\mathrm{X}$ & & $\mathrm{X}$ & 2 \\
\hline Indonesia post & $\mathrm{X}$ & & & 2 \\
\hline Korea pre & $\mathrm{X}$ & & $\mathrm{X}$ & 3 \\
\hline Korea post & $\mathrm{X}$ & & & 2 \\
\hline Malaysia pre & $\mathrm{X}$ & & $\mathrm{X}$ & 1 \\
\hline Malaysia post & $\mathrm{X}$ & & & 2 \\
\hline Philippines pre & $\mathrm{X}$ & $\mathrm{X}$ & & 1 \\
\hline Philippines post & $\mathrm{X}$ & & $\mathrm{X}$ & 2 \\
\hline Singapore pre & $\mathrm{X}$ & $\mathrm{X}$ & & 2 \\
\hline Singapore post & $\mathrm{X}$ & & & 1 \\
\hline Thailand pre & $\mathrm{X}$ & & $\mathrm{X}$ & 2 \\
\hline Thailand post & $\mathrm{X}$ & & & 2 \\
\hline
\end{tabular}

Note: X means the specifications that used in the SVAR model.
The results of SVAR can be studied from the long-run impact matrix, impulse response function and forecast error variance decomposition. The results of long-run impact matrix are summarized in Table 3. We follow the Blanchard Quah identification such that the upper triangular of the long run impact matrix is identified to be zero. The identification implies that the real shock of current account balance has long run impacts on the nominal shocks of CPI and exchange rate but the nominal shocks have no long run impact on the real variable.

From Table 3, we observe that the real shock has positive impact on current account balance in all cases but the impacts of shock change between the two sub-periods. The impact of real shock on current account balance has declined in Indonesia, Korea and Singapore but increases in Malaysia and Philippines. The real shock has either positive of negative impact on CPI and exchange rate. An increase in current account balance (or real shock) implies the improvement in trade balance, i.e. export is larger than import. This will lead to appreciation in domestic currency (decline in exchange rate) and relatively lower foreign demand on export as domestic price is more expensive. Lower demand leads to the drop in CPI. On the other hand, appreciation in domestic currency can lead to higher investment, hence higher price or CPI. The increase in CPI 


\begin{tabular}{|c|c|c|c|c|c|c|}
\hline \multirow{3}{*}{$\begin{array}{c}\text { Country } \\
\text { Period } \\
\text { Indonesia }\end{array}$} & \multicolumn{6}{|c|}{ Long-run impact matrix } \\
\hline & \multicolumn{3}{|c|}{ Pre-crisis } & \multicolumn{3}{|c|}{ Post-crisis } \\
\hline & $(0.0051 * * *$ & 0 & 0 & $(0.0022 * * *$ & 0 & 0 \\
\hline & $-0.0022 *$ & $0.0109 * *$ & 0 & $-0.0105 * *$ & $0.0509 *$ & 0 \\
\hline & $-0.0009 * *$ & $0.0011 *$ & $0.0057 * *$ & $0.0040 * * *$ & $0.0057 * *$ & $0.1368 * *$ \\
\hline \multirow[t]{3}{*}{ Korea } & $(4.5467 * * *$ & 0 & 0 & $(0.0341 *$ & 0 & 0 \\
\hline & $0.6045 * *$ & $1.2540 * *$ & 0 & $3.5970 * * *$ & $3.3178 * * *$ & 0 \\
\hline & $0.0143 *$ & $0.0079 *$ & $0.0249 * *)$ & $-0.0531 *$ & $-0.0272 * *$ & * $0.0353 *$ \\
\hline \multirow[t]{3}{*}{ Malaysia } & $(0.0426 * *$ & 0 & 0 & $(0.0776 * *$ & 0 & 0 \\
\hline & $0.0023 *$ & $0.0066^{*}$ & 0 & $0.0027^{*}$ & $0.0061 * *$ & 0 \\
\hline & $0.0051^{*}$ & $0.0154 * *$ & $0.0236^{*}$ & $-0.0274 * *$ & $0.0075^{*}$ & $0.0329 * *$ \\
\hline \multirow[t]{3}{*}{ Philippines } & $(0.0242 * *$ & 0 & 0 & $0.1908 * *$ & 0 & 0 \\
\hline & $0.0042 *$ & $0.0303 * *$ & 0 & $0.3781 * * *$ & $0.1233 * *$ & 0 \\
\hline & $0.0165 * *$ & $0.0299 * *$ & $0.0241 * *$ & $0.0033^{*}$ & $-0.0050 *$ & $0.0272 * *$ \\
\hline \multirow[t]{3}{*}{ Singapore } & $\left(0.0716^{* *}\right.$ & 0 & 0 & $(0.0339 * *$ & 0 & 0 \\
\hline & $0.0002 *$ & $0.0048 *$ & 0 & $-0.0081 *$ & $0.0093 *$ & 0 \\
\hline & $-0.0052 *$ & $-0.0062 *$ & $0.0120 * *$ & $-0.0050 *$ & $-0.0012 *$ & $0.0234 * *$ \\
\hline \multirow[t]{3}{*}{ Thailand } & \multirow{3}{*}{\multicolumn{3}{|c|}{ Unavailable }} & $(0.0008 *$ & 0 & 0 \\
\hline & & & & $-0.0037 * *$ & $0.0123 *$ & 0 \\
\hline & & & & $0.0197 * *$ & $-0.0549 * *$ & $0.0561 * *$ \\
\hline
\end{tabular}

TABLE 4(a): FEVD - CURRENT ACCOUNT BALANCE

\begin{tabular}{l|l|c|c|c|c|c|c}
\hline Country & Period & \multicolumn{2}{|c}{$\begin{array}{r}\text { FEVD for Current } \\
\text { Account/ GDP }\end{array}$} & \multicolumn{3}{|c}{$\begin{array}{r}\text { FEVD for Current } \\
\text { Account/GDP }\end{array}$} \\
\hline & & $\mathcal{E}^{y}$ & $\mathcal{E}^{c p i}$ & $\mathcal{E}^{e x}$ & $\mathcal{E}^{y}$ & $\mathcal{E}^{c p i}$ & $\mathcal{E}^{e x}$ \\
\hline Indonesia & Q1 & 0.78 & 0.00 & 0.22 & 0.94 & 0.06 & 0.00 \\
& Q4 & 0.58 & 0.02 & 0.40 & 0.93 & 0.06 & 0.00 \\
& Q8 & 0.58 & 0.02 & 0.40 & 0.93 & 0.07 & 0.00 \\
\hline Korea & Q1 & 0.98 & 0.02 & 0.00 & 0.53 & 0.40 & 0.07 \\
& Q4 & 0.58 & 0.01 & 0.41 & 0.57 & 0.37 & 0.05 \\
& Q8 & 0.58 & 0.02 & 0.41 & 0.58 & 0.37 & 0.05 \\
\hline Malaysia & Q1 & 0.89 & 0.01 & 0.10 & 0.75 & 0.15 & 0.10 \\
& Q4 & 0.85 & 0.01 & 0.14 & 0.65 & 0.22 & 0.13 \\
& Q8 & 0.86 & 0.01 & 0.13 & 0.65 & 0.22 & 0.13 \\
\hline Philippines & Q1 & 0.64 & 0.01 & 0.35 & 1.00 & 0.00 & 0.00 \\
& Q4 & 0.49 & 0.02 & 0.49 & 1.00 & 0.00 & 0.00 \\
& Q8 & 0.48 & 0.02 & 0.49 & 1.00 & 0.00 & 0.00 \\
\hline Thailand & Q1 & 0.66 & 0.09 & 0.25 & 0.90 & 0.10 & 0.00 \\
& Q4 & 0.39 & 0.06 & 0.56 & 0.71 & 0.28 & 0.01 \\
& Q8 & 0.39 & 0.07 & 0.54 & 0.71 & 0.28 & 0.01 \\
\hline Singapore & Q1 & 1.00 & 0.00 & 0.00 & 0.86 & 0.14 & 0.00 \\
& Q4 & 1.00 & 0.00 & 0.00 & 0.78 & 0.22 & 0.00 \\
& Q8 & 1.00 & 0.00 & 0.00 & 0.78 & 0.22 & 0.00 \\
\hline
\end{tabular}

TABLE 4(b): FEVD - CPI

\begin{tabular}{l|l|l|l|l|l|l|l}
\hline Country & Period & \multicolumn{3}{|c|}{ FEVD for CPI } & \multicolumn{3}{c}{ FEVD for CPI } \\
\hline & & $\mathcal{E}^{y}$ & $\mathcal{E}^{c p i}$ & $\mathcal{E}^{e x}$ & $\mathcal{E}^{y}$ & $\mathcal{E}^{c p i}$ & $\mathcal{E}^{e x}$ \\
\hline Indone & Q1 & 0.04 & 0.94 & 0.02 & 0.01 & 0.70 & 0.29 \\
sia & Q4 & 0.04 & 0.91 & 0.05 & 0.03 & 0.83 & 0.13 \\
& Q8 & 0.04 & 0.91 & 0.05 & 0.04 & 0.81 & 0.14 \\
\hline Korea & Q1 & 0.00 & 1.00 & 0.00 & 0.54 & 0.46 & 0.00 \\
& Q4 & 0.00 & 0.97 & 0.03 & 0.54 & 0.46 & 0.00 \\
& Q8 & 0.00 & 0.96 & 0.04 & 0.54 & 0.46 & 0.00 \\
\hline Malays & Q1 & 0.00 & 1.00 & 0.00 & 0.00 & 1.00 & 0.00 \\
ia & Q4 & 0.02 & 0.51 & 0.47 & 0.06 & 0.86 & 0.08 \\
& Q8 & 0.01 & 0.56 & 0.43 & 0.06 & 0.85 & 0.08 \\
\hline Philipp & Q1 & 0.00 & 1.00 & 0.00 & 0.19 & 0.78 & 0.03 \\
ines & Q4 & 0.03 & 0.68 & 0.29 & 0.19 & 0.76 & 0.05 \\
& Q8 & 0.03 & 0.62 & 0.35 & 0.19 & 0.75 & 0.07 \\
\hline Thailan & Q1 & 0.00 & 1.00 & 0.00 & 0.24 & 0.73 & 0.03 \\
d & Q4 & 0.36 & 0.33 & 0.31 & 0.25 & 0.71 & 0.04 \\
& Q8 & 0.38 & 0.22 & 0.40 & 0.25 & 0.71 & 0.04 \\
\hline Singap & Q1 & 0.00 & 0.99 & 0.01 & 0.43 & 0.57 & 0.00 \\
ore & Q4 & 0.00 & 0.97 & 0.03 & 0.43 & 0.57 & 0.00 \\
& Q8 & 0.00 & 0.96 & 0.03 & 0.43 & 0.57 & 0.00 \\
\hline
\end{tabular}

TABLE 4(c): FEVD - EXCHANGE RATE

\begin{tabular}{l|l|c|c|c|c|c|c}
\hline Country & Period & \multicolumn{2}{|c|}{ FEVD for exchange } & \multicolumn{3}{c}{ FEVD for exchange } \\
& & \multicolumn{2}{|c|}{ rate } & \multicolumn{3}{c}{ rate } \\
\hline \multirow{2}{*}{ Indonesia } & & $\mathcal{E}^{y}$ & $\mathcal{E}^{c p i}$ & $\mathcal{E}^{e x}$ & $\mathcal{E}^{y}$ & $\mathcal{E}^{c p i}$ & $\mathcal{E}^{e x}$ \\
& & 0.05 & 0.03 & 0.92 & 0.02 & 0.28 & 0.70 \\
& Q4 & 0.05 & 0.03 & 0.92 & 0.03 & 0.23 & 0.74 \\
& Q8 & 0.05 & 0.03 & 0.92 & 0.03 & 0.26 & 0.71 \\
\hline Korea & Q1 & 0.00 & 0.00 & 1.00 & 0.05 & 0.28 & 0.67 \\
& Q4 & 0.05 & 0.01 & 0.94 & 0.41 & 0.18 & 0.41 \\
& Q8 & 0.05 & 0.01 & 0.94 & 0.41 & 0.19 & 0.40 \\
\hline Malaysia & Q1 & 0.00 & 0.00 & 1.00 & 0.00 & 0.00 & 1.00 \\
& Q4 & 0.02 & 0.05 & 0.93 & 0.07 & 0.03 & 0.90 \\
& Q8 & 0.02 & 0.08 & 0.90 & 0.09 & 0.06 & 0.86 \\
\hline Philippines & Q1 & 0.00 & 0.00 & 1.00 & 0.09 & 0.01 & 0.90 \\
& Q4 & 0.04 & 0.02 & 0.94 & 0.20 & 0.01 & 0.79 \\
& Q8 & 0.04 & 0.02 & 0.94 & 0.21 & 0.01 & 0.78 \\
\hline Thailand & Q1 & 0.00 & 0.00 & 1.00 & 0.06 & 0.04 & 0.90 \\
& Q4 & 0.26 & 0.06 & 0.68 & 0.19 & 0.07 & 0.74 \\
& Q8 & 0.33 & 0.08 & 0.59 & 0.19 & 0.08 & 0.73 \\
\hline Singapore & Q1 & 0.15 & 0.00 & 0.85 & 0.04 & 0.00 & 0.95 \\
& Q4 & 0.14 & 0.05 & 0.81 & 0.04 & 0.00 & 0.95 \\
& Q8 & 0.14 & 0.05 & 0.81 & 0.04 & 0.00 & 0.95 \\
\hline
\end{tabular}

leads to depreciation in domestic currency (exchange rate increases). We observe that the impact of real shock on CPI has increased apparently in the post-crisis period in Korea and Philippines.

The nominal shock (i.e. increase in CPI) leads to higher price in all cases. On the other hand, the increase in CPI can lead to appreciation or depreciation in exchange rate. Higher price may encourage more production, hence higher growth or GDP. This later leads to appreciation (decline) in exchange rate. Also, higher price may leads to depreciation (increase) in exchange rate demand on domestic goods will decline and GDP drops. Comparing the results of two sub-periods, it is observed that higher CPI leads to appreciation in exchange rate in the post-crisis period. In contrast, many countries exhibit depreciation in exchange rate in response to higher price.

An increase in $1 \%$ in exchange rate shock leads to depreciation in exchange rate. The impact is larger in the 
post-crisis period. This condition may due to the higher flexibility in exchange rate in the post-crisis period as majority of crisis-hit Asian countries have switched from fixed to flexibility exchange rate regime after the financial crisis of 1997.

The results of impulse response function are consistent with the results of long-run impact matrix. The results of impulse response function are not shown here due to the space limitation. Under the Blanchard Quah identification, the upper triangular part of the impulse response functions show the tendency to approach the zero, i.e. the nominal shocks has no long run impact on the real variable (current account balance). The nominal shocks only have short run or temporary impacts on current account balance. Comparing the results of the two sub-periods, we observe that an increase of $1 \%$ nominal shock (depreciation in exchange rate) leads to increase in current account balance in the pre-crisis period. The impulse of the shock disappears in the long run. The result can be interpreted as follows: depreciation in exchange rate leads to higher demand on export as the price of domestic goods is cheaper relative to that of foreign goods. Higher demand on export leads to improvement in trade balance and current account. Conversely, appreciation in exchange rate will bring distortion in current account balance.

On the other hand, we observe that majority Asian countries exhibit decline in current account in response to depreciation in exchange rate in the post-crisis period. The decline in current account balance may due to lower demand of domestic goods by domestic households because depreciation in exchange rate implies lower buying power of domestic households. The decline in current account can also be explained by the drop in foreign investment in domestic market following depreciation in domestic currency. Conversely, appreciation in exchange rate may lead to the improvement in current account balance. Comparing the results of the two sub-periods, we can say that the current account condition in majority Asian country in the post-crisis period is better compare to the condition in the pre-crisis period. This is because appreciation in exchange rate has attracted more foreign investment in domestic market; the domestic households have higher buying power and the export and trade balance remain stable. The current account balance in Asia has improved.

The other impulse response functions show the results consistently to the results discussed in the long-run impact matrix. Generally, the long-run impact matrix shows the coefficients of reaction of each variable in the system equation to each single shock in the long-run based on the identification imposed.

The impacts of shocks on each variable in the system equation can also be studied through the forecast error variance decomposition (FEVD). Table 4(a, b and c) summarizes the results of FEVD for the periods of quarter 1,4 and 8 . We compare the result between pre- and post-crisis and across countries. We discuss the results on the forecast movement of CA/GDP. As observed, the real shock remains as the main determinant to the current account movement in both sub-periods in all six countries. On the other hand, the impact of nominal price shock on current account movement has increased significantly in the post-crisis period in conversely to the impact of exchange rate shock on current account movement. In the pre-crisis period, exchange rate shock has relatively large impact on the current account movement in all countries except Singapore. The impact declines subsequently to nearly zero in all countries except Malaysia. This result is related to the switch in the monetary policy regime in these economies in which majority of these economies have switched from fixed exchange rate regime to flexible exchange rate and inflation targeting after the crisis. Malaysia on the other hand, has moved from managed floating regime to fixed exchange rate regime fixed exchange rate by pegging at RM3.80 to the USD from September 1998 to July 2005. The pegged system was abandoned to a floating regime in July 2005 . We observe that exchange rate has greater impact on current account balance under fixed exchange rate regime. On the other hand, the price impulse has greater impact on current account balance under floating regime and inflation targeting regime.

The price shock is the main factor determines the movement in CPI in all cases. The real shock does not have significant impact on CPI in the pre-crisis period except Thailand. The impact of price shock on current account balance has increased subsequently in the post-crisis period except the case of Indonesia and Malaysia. On the other hand, exchange rate shock has large impact on current account balance in the pre-crisis period but the impact declines significantly in the post-crisis period. The exception case is Malaysia and Singapore in which the impact of exchange rate shock on current account balance in these economies remains low and no change between the two sub-periods.

Table 4(c) summarizes the FEVD for exchange rate movement. It is observed that exchange rate movement is mainly determined by its impulse in both sub-periods. The real shock of current account and nominal shock of price do not have significant impact on it in the pre-crisis period (except in Thailand and Singapore in which the real shock has some explanation power on exchange rate movement). In the post-crisis period, we observe that the price impulse has significant impact on exchange rate movement in Indonesia and Korea while the impact of real shock on exchange rate movement differs across countries.

The last step is to check the model using diagnostic tests. The Portmanteau and ARCH-LM tests are used to detect the autocorrelation and heteroskedasticity problems. In order for our estimation to free from the autocorrelation and heteroskedasticity problems, we must accept the null hypothesis of non autocorrelation and non-heteroskedasticity. The results of diagnostic tests are summarized in Table 5. As observed, our estimations have no autocorrelation and heteroskedasticity problems. 


\begin{tabular}{|c|c|c|c|c|c|c|c|c|c|c|c|c|}
\hline \multirow{2}{*}{$\begin{array}{c}\text { Country } \\
\text { period }\end{array}$} & \multicolumn{2}{|c|}{ Indonesia } & \multicolumn{2}{|c|}{ Korea } & \multicolumn{2}{|c|}{ Malaysia } & \multicolumn{2}{|c|}{ Philippines } & \multicolumn{2}{|c|}{ Singapore } & \multicolumn{2}{|c|}{ Thailand } \\
\hline & pre & post & pre & post & pre & post & pre & post & pre & post & pre & post \\
\hline \multicolumn{13}{|c|}{ Portmanteau Test } \\
\hline t statistic & 106.673 & 97.226 & 92.026 & 99.714 & 89.127 & 104.674 & 81.989 & 101.943 & 115.928 & 99.843 & 99.184 & 98.156 \\
\hline p-value & 0.9657 & 0.9941 & 0.8643 & 0.9836 & 0.9992 & 0.917 & 0.9999 & 0.4301 & 0.9234 & 0.9965 & 0.9910 & 0.9928 \\
\hline \multicolumn{13}{|c|}{ ARCH-LM test } \\
\hline t-statistic & 54.2981 & 51.301 & 48.692 & 40.188 & 57.412 & 61.325 & 57.369 & 48.044 & 52.961 & 51.770 & 54.550 & 48.606 \\
\hline p-value & 0.1613 & 0.2404 & 0.3267 & 0.6756 & 0.1015 & 0.0503 & 0.1022 & 0.3505 & 0.1939 & 0.2266 & 0.1557 & 0.3298 \\
\hline
\end{tabular}

\section{Conclusion}

We conduct empirical analysis to investigate the determinants that explain the dynamic in current account balances. In particular, we seek to investigate if exchange rate is one of the main determinants on current account movement. The study is focused on several Asian countries This study is motivated by the change in the current account balances from deficit to surplus after the financial crisis of 1997. We wonder if the switch in the monetary policy regime of majority countries from fixed exchange rate to floating regime and inflation targeting and the exchange rate flexibility can explain the dynamic in the current account in these countries.

Applying a structural VAR model, our results review that the impact of exchange rate shock on current account balance had declined apparently between two sub-periods in all economies, especially in the case of Korea Philippines and Thailand. i.e.: these three economies, exchange rate shock has impact on current account balances in the pre-crisis, but after the crisis, the impacts on current account balances are from current account and/or CPI shocks. Therefore, the conclusion is exchange rate shock had no significant impact on current account balances after the crisis in ASEAN economies except Malaysia. The main determinants of current account balances after the crisis are mainly from current account real shock and CPI nominal shocks. Current account is mainly determined by the real shock. We observe that the switch in the monetary policy between the two sub-periods has significant impact on the dynamic of current account in these economies. Under the fixed exchange rate regime in the pre-crisis period, exchange rate has relatively large impact on the movement of current account. However, the impact is not significant under the flexible exchange rate regime. Under the flexible exchange rate and inflation targeting regime, the price impulse has significant impact on current account movement. Besides, the results imply better current account condition in the post-crisis period compare to the pre-crisis period.

\section{REFERENCES}

[1] J.W. Gruber, and S. Kamin, "Explaining the global pattern of current account imbalances", Board of Governors of the Federal Reserve System, Internatioonal Finance Discussion Papers 846, 2005.

[2] E.R. Prasad, and A. Subramanian, "The paradox of capital", Finance and Development, vol. 44(1), IMF, 2007.

[3] J.W. Gruber, and S. Kamin, "Explaining the global pattern of current account imbalances", Board of Governors of the Federal Reserve System, Internatioonal Finance Discussion Papers 846, 2005.

[4] E.R. Prasad, and A. Subramanian, "The paradox of capital", Finance and Development, vol. 44(1), IMF, 2007.

[5] S. Hermann, A. Winkler, "Financial markets and the current account: emerging Europe versus emerging Asia", Review of World Economics, vol. 145, pp. 531-550, 2009a.

[6] S. Hermann, and A. Winkler, "Real convergence, financial markets and the current account-emerging Europe versus emerging Asia", North American Journal of Economics and Finance, vol. 20, pp. 100-123, 2009b.

[7] M. D. Chinn, and H. Ito, "Current account balances, Financial development and institutions: assaying the world's saving glut", University of Wisconsin \& NBER and Portland State University, 2008.

[8] M. D. Chinn, and H. Ito, "Global current account imbalances: American fiscal policy versus East Asian savings", Review of International Economics, vol. 16(3), pp. 479-498, 2006.

[9] J. Lee, and M. D. Chinn, "Current account and real exchange rate dynamics in the G7 countries", Journal of International Money and Finance, vol. 25, 2006, pp. 257-274.

[10] M. G. Arghyrou, and G. Chortareas, "Current account imbalances and real exchange rates in the Euro area", Review of International Economics, vol. 9(5), pp. 747-764, 2008.

[11] O. Arratibel, D. Furceri, R. Martin, and A. Zdzienicka, "The effect of nominal exchange rate volatility on real macroeconomic performance in the CEE countries", Economic Systems, vol. 35(2), pp. 261-277, 2011.

[12] C. Pancaro, and R. Bueffer, "Current account adjustments in industrial countries: does the exchange rate regime matter?" European University Institute and European Central Bank, 2009.

[13] A. A. Elbushra, O. E. Elsheikh, and A. A. A. Salih, "Impact of exchange rate reforms on Suden's economy: applied general equilibrium analysis", African Journal of Agricultural Research, vol. 5(6), pp. 442-448, 2010.

[14] S. Hermann, "Do we really know that flexible exchange rates facilitate current account adjustment? Some new empirical evidence for CEE countries" Discussion paper series I: Economic Studies no. 22/2009. Deutsche Bundesbank, 2009.

[15] Y. W. Cheung, M. D. Chinn, and E. Fujii, "China's current account and exchange rate", NBER working paper no. 14673, 2009.

[16] S. C. Devkota, "Impact of exchange rate change on foreign trade balance in Nepal", EconWPA, 2004.

[17] M. Obstfeld, and K. S. Rogoff, "Global current account imbalances and exchange rate adjustments", Brookings Institution Press 1, pp. 67-146, 2005.

[18] M. Fratzscher, L. Juvenal, and L. Sarno, "Asset prices, exchange rates and the current account", ECB working paper no. 790, 2007.

[19] O. J. Blanchard, and D. Quah, "The dynamic effects of aggregate demand and supply disturbances", American Economic Review, vol. 79(4), pp. 655-673, 1989.

[20] C. A. Fayero, Applied macroeconomics; Oxford University Press, 2001. 